\title{
Studi Deskriptif tentang Sarana dan Prasarana Bimbingan dan konseling di Sekolah Menengah Pertama
}

\author{
Dwi Putranti \\ Program Studi Bimbingan dan konseling Universitas Ahmad Dahlan Yogyakarta \\ J1. Pramuka No. 42, Sidikan, Yogyakarta, Indonesia \\ Email: dwiputranti@gmail.com
}

\begin{abstract}
This study aims to describe the availability of facilities and infrastructure for guidance and counseling of Muhammadiyah Junior High Schools in Yogyakarta. This research is a survey with mixed method approach. The participants were 10 Muhammadiyah Junior High Schools in Yogyakarta. The data collection instruments are questionnaires containing semi-open questions on the availability of facilities and infrastructure checklist for guidance and counseling at the schools. This study used descriptive statistical techniques as the data analysis. The results showed three findings, they are, 1) the availability of counseling rooms were adequate according to the standard which measured $8 \times 9 \mathrm{~m}$, at five schools, or $50 \%$ out of the 10 schools that became the participants of this research, 2 ) the availability of particular rooms for guidance and counseling are owned by eight schools $(80 \%)$, 3) the obstacles of the availiabity of guidance and counseling facilities and infrastructures are the fundings and the limited area. The results of the study provides an information for the school parties especially who are involved in the development of facilities and infrastructure in schools, such as, the principals, the homeroom teachers and subject teachers about the limited facilities of guidance and counseling services to the students.
\end{abstract}

Keywords: availability, facilities and infrastructure, guidance and counseling services

\begin{abstract}
Penelitian ini bertujuan untuk menggambarkan sarana dan prasarana bimbingan dan konseling di Sekolah Menengah Pertama Muhammadiyah Yogyakarta. Penelitian ini menggunakan pendekatan mixed method dengan jenis penelitian survei. Subjek penelitian berjumlah sepuluh Sekolah Menengah Pertama di kota Yogyakarta. Instrumen pengumpulan data berupa kuesioner semi terbuka yang berisi tentang checklist ketersediaan sarana dan prasarana bimbingan dan konseling di sekolah. Teknik analisis data dalam penelitian ini menggunakan statistik deskriptif dengan teknik persentase. Hasil penelitian menunjukkan 1) ketersediaan ruang bimbingan dan konseling yang memadai sesuai standar yaitu berukuran $8 \times 9 \mathrm{~m}$, pada lima sekolah atau sebesar $50 \%$ dari 10 sekolah yang menjadi subyek penelitian; 2) ketersediaan ruang khusus konseling dimiliki oleh delapan sekolah $(80 \%)$ dari sepuluh sekolah; 3) faktor penghambat ketersediaan sarana bimbingan konseling yaitu faktor biaya dan keterbatasan lahan. Hasil penelitian ini memberikan informasi bagi bidang pengembangan sarana dan dan prasarana sekolah, kepala sekolah, wali kelas, dan guru mata pelajaran mengenai keterbatasan fasilitas guru dalam memberikan layanan bimbingan dan konseling kepada siswa.
\end{abstract}

Kata kunci: ketersediaan, sarana dan prasarana, layanan bimbingan dan konseling

\section{Pendahuluan}

Menurut Undang-undang Nomor 20 tahun 2003 konselor adalah pendidik. Profesi konselor sejajar dengan guru, dosen, pamong belajar, tutor, widyaiswara, fasilitator, dan instruktur sebagai pendidik profesional. Masing-masing kualifikasi pendidik, termasuk konselor, memiliki ekspektasi kinerja yang unik. Ekspektasi kinerja konselor dalam menyelenggarakan pelayanan ahli bimbingan dan konseling senantiasa digerakkan oleh motif altruistik, sikap empatik, menghormati keragaman, serta mengutamakan kepentingan konseli, dengan selalu mencermati dampak jangka panjang dari pelayanan yang diberikan (Permendiknas No. 27 tahun 2008).

Keberadaan UU No. 20 tahun 2003 dan Pemendiknas No. 27 tahun 2008 tersebut menunjukkan bahwa bimbingan konseling adalah salah satu komponen yang penting dalam mendorong tercapainya tujuan pendidikan. Dalam modul pelatihan implementasi kurikulum 2013 untuk guru bimbingan dan konseling/konselor, dijelaskan bahwa kurikulum 2013 dirancang dengan tujuan untuk mempersiapkan insan Indonesia supaya memiliki kemampuan hidup sebagai pribadi dan 


\section{PUTRANTI}

warganegara yang produktif, kreatif, inovatif, dan afektif serta mampu berkontribusi pada kehidupan bermasyarakat, berbangsa, bernegara, dan peradaban dunia. Dalam rangka implementasi kurikulum 2013 yang mengamanatkan adanya peminatan peserta didik pada kelompok mata pelajaran, lintas mata pelajaran, dan pendalaman mata pelajaran maka diperlukan adanya pelayanan Bimbingan dan konseling yang dilakukan oleh guru Bimbingan dan konseling atau konselor. Implementasi kurikulum 2013 tentu membutuhkan usaha dan kinerja yang lebih dari konselor.

Kurikulum 2013 memuat program peminatan peserta didik yang merupakan suatu proses pemilihan dan pengambilan keputusan oleh peserta didik yang didasarkan atas pemahaman potensi diri dan peluang yang ada pada satuan pendidikan. Muatan peminatan peserta didik meliputi peminatan kelompok mata pelajaran, mata pelajaran, lintas peminatan, pendalaman peminatan dan ekstra kurikuler. Dalam kontekstersebut, layanan bimbingan dan konseling membantu peserta didik untuk memahami, menerima, mengarahkan, mengambil keputusan, dan merealisasikan keputusan dirinya secara bertanggungjawab sehingga mencapai kesuksesan, kesejahteraan dan kebahagiaan dalam kehidupannya.Bimbingan dan konseling membantu peserta didik/konseli dalam memilih, meraih dan mempertahankan karir untuk mewujudkan kehidupan yang produktif dan sejahtera.

Sesuai dengan arah dan spirit Kurikulum 2013, paradigma bimbingan dan konseling memandang bahwa setiap peserta didik/konseli memiliki potensi untuk berkembang secara optimal. Perkembangan optimal bukan sebatas tercapainya prestasi sesuai dengan kapasitas intelektual dan minat yang dimiliki, melainkan sebagai sebuah kondisi perkembangan yang memungkinkan peserta didik mampu mengambil pilihan dan keputusan secara sehat dan bertanggungjawab serta memiliki daya adaptasi tinggi terhadap dinamika kehidupan yang dihadapinya.

Setiap peserta didik/konseli satu dengan lainnya berbeda dalam hal kecerdasan, bakat, minat, kepribadian, kondisi fisik dan latar belakang keluarga serta pengalaman belajarnya. perbedaan tersebut menggambarkan adanya variasi kebutuhan pengembangan secara utuh dan optimal melalui layanan bimbingan dan konseling. layanan bimbingan dan konseling mencakup kegiatan yang bersifat pencegahan, perbaikan dan penyembuhan, pemeliharaan dan pengembangan.

Layanan bimbingan dan konseling dalam implementasi kurikulum 2013 dilaksanakan oleh konselor atau guru bimbingan dan konseling sesuai dengan tugas pokoknya dalam upaya membantu tercapainya tujuan pendidikan nasional, dan khususnya membantu peserta didik/konseli mencapai perkembangan diri yang optimal, mandiri, sukses, sejahtera dan bahagia dalam kehidupannya. untuk mencapai tujuan tersebut diperlukan kolaborasi dan sinergisitas kerja antara konselor atau guru bimbingan dan konseling, guru mata pelajaran, pimpinan sekolah/madrasah, staf administrasi, orang tua, dan pihak lainyang dapat membantu kelancaran proses dan pengembangan peserta didik/konseli secara utuh dan optimal dalam bidang pribadi, sosial, belajar, dan karir.

Berdasarkan pemaparan di atas, pada kurikulum 2013 profesi bimbingan dan konseling menjadi profesi yang semakin memiliki peran di dunia pendidikan. profesi bimbingan dan konseling telah diberi kesempatan untuk menjadi profesi yang bermartabat dan diakui oleh masyarakat. hal ini tentu menjadi sebuah tantangan pada konselor itu sendiri untuk bisa menjawab tantangan tersebut dengan kinerja yang maksimal. akan tetapi, berbagai macam problematika muncul seiring dengan berkembangnya profesi konselor di indonesia.

Bimbingan dan konseling dapat dikatakan sebagai "soko guru" yang ketiga dalam sistem pendidikan di sekolah selain pembelajaran (instruksional) dan administrasi sekolah. sebagai sub-sistem pendidikan di sekolah, bimbingan dan konseling dalam gerak dan pelaksanaannya tidak pernah lepas dari perencanaan yang seksama dan bersistem. hal ini bertujuan agar pencapai hasil dalam konteks kontribusinya bagi pencapaian tujuan pendidikan di sekolah dapat terlihat.

Uman suherman (2007) menegaskan untuk tercapainya program perencanaan bimbingan dan konseling yang efektif dan efisien, maka ada beberapa hal yang harus dilakukan yaitu: analisis kebutuhan siswa, penentuan tujuan bimbingan dan konseling, analisis situasi sekolah, penentuan 


\section{SARANA, PRASARANA BIMBINGAN DAN KONSELING}

jenis kegiatan yang akan dilaksanakan, penetapan metode pelaksanaan kegiatan, penetapan personel kegiatan, persiapan fasilitas dan biaya kegiatan, dan perkiraan tentang hambatan kegiatan dan antisipasinya. Amanat Permendikbud no 111 tahun 2014 penyelenggaraan layanan bimbingan dan konseling yang efektif dan efisien untuk mencapai tujuan layanan dan membantu tercapainya tujuan pendidikan nasional memerlukan sarana, prasarana, dan pembiayanan yang memadai.

Penelitian ini bertujuan untuk mengetahui dan mendiskripsikan sarana dan prasarana bimbingan dan konseling di sekolah. Sarana dan prasana bimbingan dan konseling di sekolah sangat diperlukan guru bimbingan dan konseling sebagai fasilitas dalam menyelenggarakan layanan bimbingan dan konseling yang efektif dan efisien kepada siswa. Hasil penelitian ini memberikan informasi bagi bidang pengembangan sarana dan prasarana sekolah, kepala sekolah, dan stake holder mengenai kondisi sarana dan prasarana bimbingan dan konseling di sekolah sehingga dapat dijadikan dasar dalam membuat kebijakan pengadaan sarana dan prasarana bimbingan dan konseling di sekolah.

\section{KajianLiteratur}

\section{Sarana dan Prasaranan Bimbingan dan konseling}

Ketersediaan sarana prasarana pendukung ikut memberikan andil cukup besar terhadap keefektifan layanan bimbingan dan konseling secara keseluruhan. Salah satu item dalam akreditasi sekolah juga menyingung ketersediaan sarana dan prasarana bimbingan dan konseling.Sarana dan prasarana tersebut meliputi ketersediaan ruang bimbingan dan konseling serta alat pendukung lainnya.Gysbers (2012)menegaskan dalam perencanaan program bimbingan dan konseling salah satu indikator penting yang yang harus diperhatikan yaitu ketersediaan sarana dan prasarana pendukung. Schmidt (2008) mengemukakan ketersediaan sarana prasarana bimbingan dan konseling dipengaruhi oleh dukungan sistem sekolah terdapat bimbingan dan konseling. Dukungan sistem meliputi kebijakan-kebijakan terkait bimbingan dan konseling termasuk didalamnya penyediaan fasilitas yang memadai. Menurut Permendikbud no 111 Tahun 2014ukuran ruang bimbingan dan konseling harus disesuaikan dengankebutuhan jenis dan jumlah ruangan.

Ruang kerja konselor atau guru bimbingan dan konselor disiapkan secara terpisah dan antar ruangan tidak tembus pandang dan suara. Jenis ruangan yang diperlukan antara antara lain (1) ruang kerja sekaligus ruang konseling individual, (2) ruang tamu, (3) ruang bimbingan dan konseling kelompok, (4) ruang data, (5) ruang konseling pustaka (bibliocounseling) dan (6) ruang lainnya sesuai dengan perkembangan profesi bimbingan dan konseling. Jumlah ruang disesuaikan dengan jumlah peserta didik/konseli dan jumlah konselor atau guru bimbingan dan konseling yang ada pada satuan pendidikan. Menurut Depdiknas (2008) idealnya ruang bimbingan dan konseling berukuran 8 x 9 m. Sedangkan ruang konseling 3 x $3 \mathrm{~m}$.

\section{Metode Penelitian}

Penelitian ini merupakan mixed method dengan jenis penelitian survei.Waktu Penelitiian dimulai Juli-September 2015. Tempat penelitian adalah 10 (sepuluh) SMP Muhammadiyah di bawah naungan Pimpinan Daerah Muhammadiyah Kota Yogyakarta. Subjek dalam penelitian iniyaituguru bimbingan dan konseling atau koordinator bimbingan dan konseling di 10 (sepuluh) SMP Muhammadiyah di bawah naungan Pimpinan Daerah Muhammadiyah Kota Yogyakarta.

Instrumen yang digunakan adalah angket semi terbuka. Angket model ini dipilih karena memudahkan guru bimbingan konseling memberikan jawabaan. Dilihat dari cara pengisian angket menggunakan metode checklist. Instrumen ini dikembangkan berdasarkan sarana dan prasarana minimal sesuai dengan Permendikbud no 111 Tahun 2014 tentang Bimbingan dan konseling di Sekolah Dasar dan Sekolah Menengah, antara lain: 1) ruang bimbingan konseling (terdiri dari: ruang kerja sekaligus ruang konseling individual, ruang tamu, ruang bimbingan dan konseling kelompok, ruang data, ruang konseling pustaka, dan ruang lainnya sesuai dengan perkembangan profesi bimbingan dan konseling); 2) fasilitas 


\section{PUTRANTI}

penunjang (dokumen program bimbingan dan konseling, instrumen pengumpul data); 3) pembiayaan (anggaran program bimbingan dan konseling, anggaran untuk aktivitas pendukung, dan anggaran untuk pengembangan dan peningkatan kenyamanan ruang).

Analisis data dalam penelitian ini adalah dengan menggunakan statistik deskriptif dengan teknik persentase, yaitu statistik yang berfungsi untuk mendeskrepsikan atau memberi gambaran terhadap obyek yang diteliti melalui sampel atau populasi sebagaimana adanya. Teknik persentase dalam analisis data dengan menggunakan kategori punya dan tidak punya.

\section{Hasil Penelitian dan Pembahasan}

Penelitian ini bertujuan untuk mengetahui ketersediaan sarana prasana bimbingan dan konseling di sekolah sebagaimana Gambar 1. Subyek penelitian adalah 10 sekolah menengah pertama di bawah naungan Pimpinann Daerah Muhammadiyah Kota Yogyakarta.

1. Tersediaan ruang bimbingan dan konseling minimal 9m (sesuai borang akreditasi sekolah)

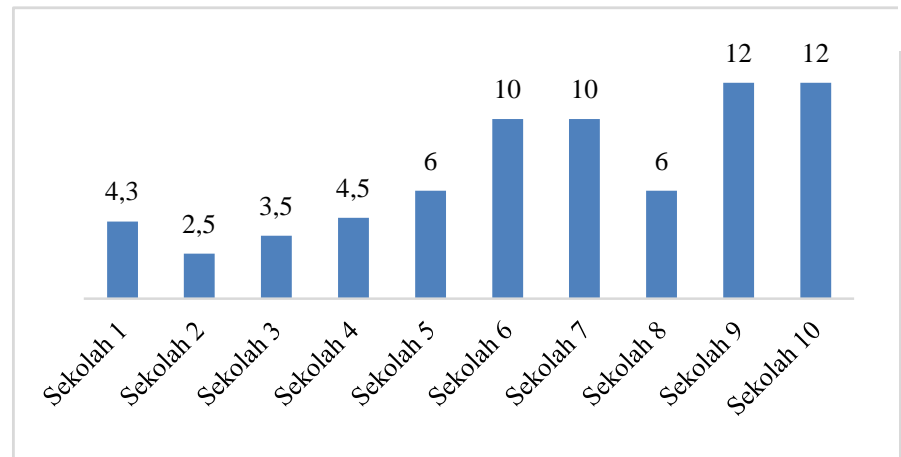

Gambar 1

Ketersediaan Ruang Bimbingan dan Konseling

Dari data diatas baru 5 sekolah yang memenuhi syarat ruangan minimal $9 \mathrm{~m}$ sesuai amanat dalam borang akreditasi sekolah.

2. Ketersediaan ruangan konseling individu.

Ketersediaan ruangan konseling individu diperlukan karena menunjang keterlaksanaan layanan konseling iindividual. Dari 10 sekolah, 8 sekolah memiliki ruang khusus untuk konseling sebagaimana digambarkan dalam Gambar 2.

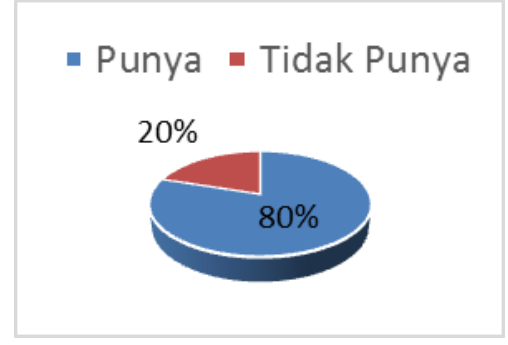

Gambar 2

Ketersediaan Ruang Konseling Individu

Pelayanan bimbingan konseling terbagi dalam layanan individu, kelompok, klasikal, layanan bimbingan yang memerlukan perhatian khusus adalah konseling individu. Dimana dalam layanan ini terdapat interaksi khusus serta bersifat rahasia. Maka dukungan ruangan konseling mutlak diperlukan dalam rangka menunjang keberhasilan layanan bimbingan dan konseling.

Pelaksanaan layanan konseling individu didukung dengan ruangan yang nyaman, tidak bisa didengar pihak lain. Jika ruang tidak dimiliki kegiatan konseling dpaat dilakukan seperti di mushola sekolah atau di pinggir halaman sekolah dengan mngikuti standar etika pelaksanaan layanan konseling.

\section{Ruangan Bimbingan Konseling Kelompok}

Hasil penelitian menunjukkan dari 10 sekolah baru 5 sekolah yang memiliki ruang bimbingan dan konseling kelompok sebagaimana Gambar 3. Layanan bimbingan dan konseling kelompok dilakukan sebagai alternatif lain pelayanan pada siswa dengan pengembangan dinamika kelompok. Idealnya layanan ini dilakukan di ruang khusus kegiatan kelompok. Karena keterbatasan tempat, konselor bisa mensiasati kegiatan kelompok dapat dilakukan di serambi mushola sekolah, pinggir halaman sekolah, atau di Laboratorium sekolah.

\section{- Punya - Tidak Punya}

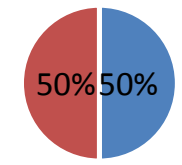

Gambar 3

Ketersediaan Ruang Bimbingan dan Konseling Kelompok 


\section{SARANA, PRASARANA BIMBINGAN DAN KONSELING}

4. Ketersediaan Fasilitas Penunjang

Fasilitas penunjang yang dimaksud penelitian ini adalah rak, almari, dan ruang penyimpanan data penting siswa. Hasil penelitian menunjukkan semua sekolah memiliki rak dan lemari khusus penyimpanan data. Namun tidak ada yang memiliki semacam ruang khusus.Layanan bimbingan konseling sebagian besar didominasi oleh bukti pelaksanaan layanan berupa laporan pelaksanaan layanna serta data hasil penyebaran instrumen. Maka diperlukan semacam tempat menyimpan data tersebut. Penyimpanan data bermanfaat untuk PKG,PAK dan akreditasi sekolah.

5. Ketersediaan Instrumen Bimbingan dan konseling

Salah satu tugas penting konselor adalah mengenal konseling secara mendalam, perlu dimiliki instrumen yang mendukung untuk mengetahui data kebutuhan siswa, Hasil penelitian menunjukkan 10 sekolah memiliki instrumen seperti, ITP, DCM, IKMS dan lain sebagainya.

Salah satu kompetensi konselor adalah memahani konseli yang hendak dilayani secara mendalam, kompetensi ini menuntut kemampuan "peka" konselor dalam memahami peserta didiknya. Tuntutan pemahaman jenisjenis alat pengumpulan data baik tes maupun nontes mutak dikuasai konselor. Sejalan dengan hal tersebut, dalam borang Penilaian Kinerja guru bimbingan dan konseling, salah satunya knselor menyusun materi berdasarkan hasil analisia kebutuhan. Penguasaan asesmen menjadi kewajiban bagi konselor.

Selain kemampuan menggunakan asesmen yang telah ada seperti AUM, DCM, ITP, IKMS, konselor seyogyanya dituntut untuk memiliki kemampuan dalam mengembangan instrumen secara mandiri. Sehinggan data yang dikumpulkan sesuai dengan kebutuhan di sekolah tersebut.

6. Hambatan Ketersediaan Sarana Prasarana Bimbingan dan konseling

Hasil penelitian menunjukkan ada dua alasan yang cukup kuat yang menghambat ketersediaan sarana dan prasarana bimbingan dan konseling yaitu faktor biaya dan keterbatasan lahan. Subyek penelitian adalah
Sekolah Muhammadiyah yang noteben adalah sekolah swasta. Sekolah swasta secara mandiri menghimpun dana untuk kegiatan operasional sekolah. Meskipun mendapatkan Dana BOS (Bantuab Operasikonal Sekolah) namun dana ini hanya berfokus pada operasional, bukan pada tataran pengembangan sumber daya. Hal ini berimpilkasi sedikitnya dana yang dapat digunakan dalam pengembangan sekolah termasuk sarana dan prasarana bimbingan dan konseling.

Sekolah Muhammadiyah rata-rata terletak pada wilayah strategis. Hal ini berimplikasi mayoritas sekolah terletak pada daerah pada penduduk, hal ini berpengaruh pada ketersediaan lahan dalam pengembangan sekolah ke depannya. Langkah yang dapat di tempuh yaitu perluasan lahan dengan cara mendirikan gedung bertingkat dan tentu cara ini membutuhkan anggaran yang cukup besar.

Keterbatasan sarana dan prasarana bimbingan dan konseling tidak menjadi faktor utama hambatan pelaksanaan layanna bimbingan dan konseling. Guru bimbingan dan konseling diituntut memiliki kreativitas dalam pengembangan model layanan-layanan yang beorientasi manfaat bagi siswa. Misalnya pada sesi konseling dpaat siasati dilakukan di pinggir halaman sekolah dengan syarat memenuhi etika profesi konselor.

\section{Simpulan}

Hasil penelitian menunjukkan bahwa belum semua sekolah memiliki ruang bimbingan dan konseling yang memadai. Selain itu, hambatan yang paling menonjol dalam terbatasnya ruang bimbingan dan konseling yaitu faktor biaya. Hasil penelitian ini memberikan informasi bagi bidang pengembangan sarana dan dan prasarana, kepala sekolah, wali kelas, dan guru mata pelajaran mengenai keterbatasan fasilitas guru bimbingan dan konseling dalam memberikan layanan bimbingan dan konseling kepada siswa, sehingga dapat membantu guru bimbingan dan konseling dalam menyediakan fasilitas yang diperlukan agar siswa merasa nyaman dalam memperoleh layanan bimbingan dan konseling di sekolah. 


\section{Referensi}

Depdiknas. (2008). Penataan Pendidikan Profesional Konselor dan Layanan Bimbingan dan konseling Dalam Jalur Pendidikan Formal. Jakarta: Depdiknas.

Gysbers, N.C. \& Henderson P. (2012). Developing and Managing Your School Guidance and Counseling Program Fourth Edition. Alexandria : American Counseling Assosiation.

Mamat Supriatna.(2011). Bimbingan dan konseling Berbasis Kompetensi. Jakarta: PT Rajagrafindo Persada

Permendiknas No 27 Tahun 2008. Standar Kompetensi Akademik dan Kualifikasi Konselor.

Permendikbud No 111 Tahun 2014 Tentang Bimbingan dan konseling Pada Pendidikan Dasar dan Pendidikan Menengah .

Schmidt, John J. (2008). Counseling in Schools: Comprehensive Programs of Responsive Service for All Student. Boston : Pearson.

Uman Suherman. (2007). Manajemen Bimbingan dan konseling. Rizki Press: Bandung. 